\title{
CORRIGENDUM
}

\section{Influence of plane of nutrition and diet composition on rumen fermentation and energy utilization by dairy cows}

J. D. SUTTON, W. H. BROSTER, E. SCHULLER, D. J. NAPPER, VALERIE J. BROSTER AND J. A. BINES

J. agric. Sci., Camb. (1988), 110, 261-270

The authors regret that there is an error in Fig. 1 of this paper. The values on the $x$-axis should be reversed to read from left to right: $200,150,100 \mathrm{~g} \mathrm{ADF} / \mathrm{kg}$ diet D.M. 